\title{
KAJIAN TEOLOGIS PENYAMPAIAN FIRMAN TUHAN DAN PENGARUHNYA BAGI PERTUMBUHAN IMAN JEMAAT
}

\author{
Wellem Sairwona \\ Universitas Kristen Indonesia \\ Program Studi Magister Pendidikan Agama Kristen \\ wellem.sairwona@uki.ac.id
}

\begin{abstract}
Abstrak:
Pemberitaan Firman Tuhan dalam sebuah komunitas kristiani di tingkat lokal ataupun regional sangat dimungkinkan untuk ditelaah dan diamati pengaruhnya terhadap pertumbuhan iman jemaat. Pemberitaan Firman Tuhan adalah pemberitaan tentang kasih dan kuasa Allah di dalam Alkitab kepada sesama manusia di dalam konteks kehidupan berjemaat, pada masa kini. Pertumbuhan iman jemaat adalah kualitas persekutuan jemaat secara pribadi dengan Kristus sebagai Kepala Gereja dan kualitas persekutuan jemaat dengan sesamanya. Jadi pertumbuhan iman memiliki dimensi vertikal sebagai sumber pertumbuhan iman secara pribadi dan dimensi horizontal sebagai sumber kesaksian kepada sesama.

Penelitian ini membuktikan bahwa pemberitaan Firman sangat penting bahkan merupakan suatu yang ultima bagi pembentukan akhlak jemaat di dalam usaha menuju keserupaan dengan Kristus. Disamping itu, pembenahan cara hidup yang terus menerus diperbaharui di dalam Roh Kudus hanya mungkin lewat asupan Firman Tuhan yang didengar. Oleh karena pertumbuhan iman seseorang dan pertumbuhan iman komunitas adalah anugerah Allah, maka tugas dari umat beriman adalah menjaga anugerah itu di dalam hidup yang disiplin dan taat kepada Firman Tuhan.

Penelitan menyimpulkan bahwa hubungan antara pemberitaan Firman Tuhan dan persekutuan jemaat dengan pertumbuhan iman jemaat adalah bersifat logis, spiritual dan adikodrati. Penelitan juga menyimpulkan bahwa dampak dari pemberitaan Firman Tuhan dan persekutuan jemaat terhadap pertumbuhan iman warga jemaat adalah bersifat positif, rasional dan Alkitabiah.
\end{abstract}

Kata Kunci: Pemberitaan Firman, Pertumbuhan Iman, Persekutuan Jemaat, Kesaksian. 


\section{Pendahuluan}

Dinamika pemberitaan Firman Tuhan dalam sebuah komunitas kristiani di tingkat lokal ataupun regional sangat dimungkinkan untuk ditelaah dan diamati eksistensinya. Hal ini berkenaan dengan realitas komune tersebut, yakni pergulatan imannya menghadapi tantangan dan perubahan yang sedang terjadi. Pengamatan dalam bingkai teologi kristen yang membumi dan penuh kewenangan sangatlah penting. Kajian otentik terhadap pergulatan iman umat dapat mengalami rasionalisasi terhadap pemberitaan Firman Tuhan. Ketika rasio cendrung bergerak secara instrumentalis, maka pemberitaan Firman Tuhan dapat dipandang sebagai tindakan komunikatif Alah kepada umat-Nya yang terkait dengan adanya harapan-harapan timbal balik antara Pencipta dengan ciptaanNya. ${ }^{1}$

Komunitas sendiri dapat dibatasi sebagai sekelompok orang dalam area geografi tertentu yang berinteraksi dalam institusi bersama, yang memiliki interdependensi dan rasa memiliki yang sama. Batasan yang dberikan Chris Shore ini $^{2}$, paling tidak dapat menggambarkan komunitas jemaat kristen, yang tergolongkan dan termasuk pada batasan ini. Heath ketika menganalisis kehidupan jemaat di Korintus berdasarkan Surat 2 Korintus menemukan dinamika kehidupan jemaat dan dalam lingkungan saudara seiman. Beliau membaginya ke dalam dua golongan. Pertama, berkenaan dengan sikap hidup berkeluarga yang wajar (hubungan suami istri), tanggungjawab dalam persekutuan kristen, prinsip-prinsip kepemimpinan dan pengajaran. Kedua,

\footnotetext{
${ }^{1}$ Kategori ini oleh Jurgen Habermas dibatasi sebagai bentuk komunikasi yang orientasinya mencari norma-norma yang valid (dan dapat dijadikan pegangan dalam hidup) dan prosesnya secara intersubjektif. Lihat Zainal Abidin Bagir, Jarot Wahyudi dan Afnan Anshori dalam Integrasi Ilmu Dan Agama (Bandung: Penerbit Mizan, 2005), 87.

${ }^{2}$ Chris Shore, "Community" dalam William Outhwaite, Pemikiran Sosial Modern (Jakarta: Kencana, 2008), 136.
}

berkenaan dengan sikap dan pelayanan kepada masyarakat di dalam lingkungan gereja. ${ }^{3}$ Menurut Heath, aspek pengajaran dan persekutuan mendapatkan perhatian penting dalam surat ini.

Komunitas adalah gambaran asosiatif keluarga, saudara seiman dan sahabat serta tetangga untuk saling mendukung satu dengan lainnya. Pratt dengan gamblang melukiskan dinamika pengajaran dan persekutuan sangat diwarnai oleh gaya hidup aktual, tendensi, loyalitas dasar dan sistem kepercayaan anggotanya. ${ }^{4}$

Kehidupan jemaat lokal ataupun regional dapat digolongkan sebagai tubuh Kristus. Dalam 1 Korintus 12 ayat 13 disebutkan, begitu juga kita semиa, baik orang Yahudi maupun orang bukan Yahudi, hamba-hamba maupun orang-orang merdeka; kita semua sudah dibaptis oleh Roh yang sama itu, supaya kita dijadikan satu pada tubuh Kristus itu. Kita semua juga mengalami Roh yang satu itu sepenuhnya (versi BIS). Dalam pengertian ini mudah untuk dimengerti bahwa memahami Kitab Suci adalah tanggung jawab semua orang percaya yang bekerja sama sebagai tubuh Kristus. Tentunya hal tersebut hanya mungkin terjadi di dalam komunitas persekutuan.

\section{Teologi Mengenai Pemberitaan Firman dan Persekutuan}

Pemberitaan Firman Tuhan dan persekutuan adalah aspek ultima bagi pengembangan iman jemaat baik di lingkungan kecil, menengah dan besar. Konotasi pemberitaan tidak semata-mata berkhotbah, tetapi di dalamnya juga termaktub pengajaran, perbaikan cara hidup dan pembinaan corak hidup baru sebagai murid Kristus.

\footnotetext{
${ }^{3}$ W. Stanley Heath, Tafsiran 2 Korintus Kedewasaan Iman (Bandung: Kalam Hidup, 2008), 11.

${ }^{4}$ Richard L. Pratt, He Gave Us Stories (Surabaya: Momentum, 2005), 77.
} 
Inilah keutamaan dari pengajaran dan persekutuan bersama, yaitu mempelajari doktrin Kristen. Senada dengan hal ini Ferguson mengatakan, doktrin membentuk kehidupan ketika bila dipelajari dengan tepat. Pemahaman doktrinal yang baik akan mempengaruhi sikap kita tanpa kita sadari dan respons kita di dalam segala macam situasi. ${ }^{5}$ Doktrin membentuk kehidupan dan menunjukkan kepada kita Allah yang kita sembah dan mengiluminasi pemahaman kita tentang kasih Anak-Nya dan karya Roh Kudus-Nya.

Kesemuanya ini menjadikan aspek pemulihan gambar dan rupa Allah menjadi mengena dalam uraian ini. Dipastikan dan ini benar, ketika seseorang belum di dalam Kristus sesungguhnya ia adalah gambar yang telah rusak. Pengajaran Firman dan persekutuan mengarah kepada pemulihan gambar dan rupa yang rusak itu. Pratt dalam bukunya yang lain menunjukkan akan arti penting kehadiran Kristus di dalam pemberitaan Firman dan persekutuan. Beliau mengutip 2 Korintus 4 ayat 4 yang mengatakan, Bapa kita di sorga mengutus Yesus untuk menjadi penyelamat segala bangsa. Ia adalah gambar Allah. ${ }^{6}$

Ada beberapa dasar bagi pemberitaan Firman Tuhan sebagai perkataan dan sakramen. Browning menuliskan, pemberitaan Injil Kristen berdasarkan Galatia 1:18, 1 Korintus 9:14 dan Filipi 1:17 serta 1 Korintus 11:26 biasa diikuti dengan pengajaran mengenai pokok-pokok iman atau pengakuan. ${ }^{7}$ Berkaitan dengan persekutuan, pemberitaan Firman Tuhan dimaknai sebagai terwujudnya hubungan-hubungan personal Allah dengan umat-Nya. Pokok bahasan ini dapat dilihat misalnya di dalam Yeremia 10:25, Yesaya 37:20 dan Hosea 4:1-2. Di dalam beberapa teks ini terlihat bahwa pengajaran Firman Tuhan melibatkan pe-

\footnotetext{
${ }^{5}$ Sinclair B. Ferguson, Kehidupan Kristen Sebuah Pengantar Doktrinal (Surabaya: Momentum, 2007), 12.

${ }^{6}$ Richard L. Pratt, Designed For Dignity (Surabaya: 2002),24.

${ }^{7}$ W.R.F. Browning, Kamus Alkitab (Jakarta: BPK Gunung Mulia, 2007), 316.
}

rasaan dan hubungan pribadi (personalrelation). Dalam khasanah Perjanjian Baru, misalnya pengajaran Firman Tuhan juga mencakup kepada pengetahuan tentang pekerjaan Allah dan pengetahuan ini tampak dalam kasih (1 Korintus 13:2) dan karunia Roh (1 Korintus 12:8). Muaranya bertumpu kepada Penciptaan dan Penebusan Allah.

Inilah yang dilihat oleh Pratt sebagai keunikan khas golongan Kristen, di mana kehidupan mereka menyentuh banyak bidang kehidupan. ${ }^{8}$ Hal ini riil dan konkrit oleh karena gereja dibangun dan membangun dirinya di atas Kristus dan bersandar pada pengorbanan-Nya sebagai pembayaran atas dosa-dosa kita. Oleh karena itu, kita beribadah melalui perantaraan keimaman Kristus. Itu sebabnya sakramen baptisan dan perjamuan kudus dilaksanakan di dalam gereja sebab ke dua hal ini yang secara spesifik telah ditetapkan oleh Allah.

Diskursus ini membawa kepada sebuah benang merah hakikat pemberitaan Firman memiliki sentralitas utama pada karya Kristus bagi umat-Nya. Persekutuan di tengah-tengah umat Allah merupakan sebuah panggilan untuk memasuki komunitas Perjanjian Baru dan belajar menaati theokratis Kristen sebagai cara hidup baru di dalam Kristus. Van Gemeren mengatakan, tidak peduli apa latar belakang kita atau asal usul etnis kita, komunitas baru di dalam Kristus termasuk di dalamnya menerima janji-janji keselamatan Yahweh. ${ }^{9}$

Pengajaran Firman dan persekutuan dapat dilihat juga tidak hanya dari sentralitas pemberitaan serta persekutuan umat Tuhan semata. Tetapi juga dapat dilihat, dipahami dari sisi kesatuan (unity) dan keragamannya (diversity). Melalui pemberitaan Firman Tuhan, umat yang berbeda-beda dipersatukan di dalam salib Kristus. Aspek salib Kristus dapat dilihat dalam pemberitaan Firman Tuhan serta persekutuan umat tebusan-Nya. Inilah yang dikatakan oleh John Stott dengan

\footnotetext{
${ }^{8}$ Richard L. Pratt, He Gave Us Stories (Surabaya: Momentum, 2005), 414.

${ }^{9}$ Willem A Van Gemeren, Penginterpretasian Kitab Para Nabi (Surabaya: Momentum, 2007),312.
} 
mengutip doa Paulus, dalam Efesus 3:18. Stott mengatakan, "tidak heran Paulus berdoa agar bersama-sama seluruh umat Allah kita dapat memahami betapa lebarnya dan panjangnya dan tingginya dan dalamnya kasih Kristus-dimensi-dimensi yang dianggap oleh sejumlah bapa gereja mula-mula dilambangkan dalam bentuk salib." 10

Dalam pemberitaan Yesaya sebagai sebuah teladan, dampak dari pemberitaan nabi Allah ini adalah agar kaum saleh dapat memahami dan mengenal "kerygma" Yahweh dalam fasal 8 ayat 13-14 yang berbunyi: "'et-yhwh('ädönäy) cübä'ôt 'ötô

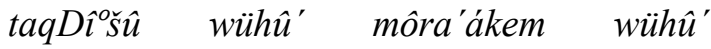

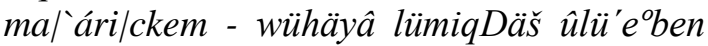
negep ûlücûr mikšôl lišnê bäTTê yiSrä'ël lüpaH v̂lümôqës lüyôšëb yürûšälä im "

Tetapi TUHAN semesta alam, Dialah yang harus kamu akui sebagai Yang Kudus; kepada-Nyalah harus kamu takut dan terhadap Dialah harus kamu gentar. Ia akan menjadi tempat kudus, tetapi juga menjadi batu sentuhan dan batu sandungan bagi kedua kaum Israel itu, serta menjadi jerat dan perangkap bagi penduduk Yerusalem.

Sebuah determinasi hidup pribadi dan pengagungan akan kebesaran Yahweh Elohim. Van Gemeren menyebutkan, kaum saleh mencari Tuhan dan menantikan kerajaan-Nya (Yesaya 8:16-17). Para pengikut Yahweh menunjukkan perbedaan dengan memisahkan diri mereka dari struktur ciptaan manusia (Yesaya 2:22), dengan menguduskan diri mereka bagi Tuhan (Yesaya 8:13), dengan mempercayai keselamatanNya (Yesaya 8:14), dan dengan tunduk kepada penyataanNya(Yesaya $8: 16,20)$ dan dengan menantikan zaman baru (Yesaya 8:17). ${ }^{11}$

Aspek psikologis dari pemberitaan Firman Tuhan dan persekutuan jemaat juga bersentuhan dengan kontak sosial anggota. Teologi sosial yang dikedepankan adalah melalui pemberitaan dan persekutuan dapat

\footnotetext{
${ }^{10}$ John Stott, The Incomparable Christ (Surabaya: Momentum, 2007), 29.

${ }^{11}$ Willem A Van Gemeren, Penginterpretasian Kitab Para Nabi (Surabaya: Momentum, 2007), 280.
}

mereduksi prasangka-prasangka yang dapat menghambat pertumbuhan iman jemaat. Gordon Allport seperti dikutip Slavin mengatakan, "Prasangka ...kemungkinan bisa dikurangi oleh status yang setara antara kontak kelompok mayoritas dan minoritas ketika mereka sedang mengusahakan tujuan bersama. Pengaruhnya akan sangat terasa apabila kontak ini didukung oleh institusi penunjang... dan apabila ada semacam pengarah yang dapat mengarahkan kepada persepsi kepentingan bersama dan rasa kemanusiaan bersama diantara para anggota kedua kelompok. ${ }^{12}$

Tepatlah jika pemberitaan Firman Tuhan sebagai pengarah dalam persekutuan mampu membawa jemaat untuk beradaptasi dengan sesamanya serta memberikan peluang secara konkrit untuk saling bertumbuh di dalam anugerah ilahi.

Sikap dan pandangan ini berakar dari teladan Kristus. Pada dasarnya, Ia juga mengatakan kepada kita, "Temukanlah apa yang seharusnya engkau lakukan, dan sajikanlah itu kepada orang lain..", ${ }^{13}$ sebuah filsafat pertumbuhan dalam kebersamaan karena saling memperhatikan dan berbagi serta melayani sama seperti Guru Agung dan Kepala Jemaat itu, yakni Kristus.

Bertumbuh di dalam anugerah itu berarti menikmati kebebasan di dalam Kristus untuk melayani sesamanya. Inilah yang disinggung juga oleh Paulus. Di dalam 1 Korintus 9:19 dan 21, batasannya orang yang bebas karena Kristus dipanggil untuk melayani sesamanya. ${ }^{14}$ Artikulasinya adalah jemaat dibawa ke dalam otoritas dan tunduk kepada pemeliharaan Allah. Pertama kali telah dikembangkan di dalam kehidupan alami manusia, dan kemudian digunakan oleh

\footnotetext{
${ }^{12}$ Robert E. Slavin, Cooperative Learning (Bandung: Nusa Media, 2008), 102.

${ }^{13}$ Myles Munroe, The Spirit of Leadership (Jakarta: Penerbit Imanuel, 2008), 97.

${ }^{14}$ Verne H. Fletcher, Lihatlah Sang Manusia (Jakarta: BPK Gunung Mulia, 2007), 265.
} 
Allah sebagai sarana bagi wahyu khusus Allah. ${ }^{15}$

Sasaran dari pemberitaan Firman Tuhan kepada persekutuan jemaat adalah agar umat Tuhan memiliki cara hidup yang bijaksana, bersikap adil dan beribadah. "Ia mendidik kita supaya kita meninggalkan kefasikan dan keinginan-keinginan duniawi dan supaya kita hidup bijaksana, adil dan beribadah di dalam dunia sekarang ini" (Titus $2: 12$ ). Dengan demikian dapat disebutkan bahwa aspek teologi dari pemberitaan Firman Tuhan dan persekutuan umat adalah belajar mengenal ketetapan-ketetapan Allah dan bertumbuh bersama dengan saudara seiman di dalam pemeliharaan Tuhan yang ajaib.

\section{Teori Pertumbuhan Iman}

Sebuah narasi merujuk kepada kehidupan yang bertumbuh dalam iman seperti yang disampaikan oleh Homrighausen dan Enklaar ${ }^{16}$, sebagai berikut: Berbahagialah gereja yang mempunyai banyak keluargakeluarga Kristen sejati. Apa yang dipelajari anak-anak dalam keluarganya sejak kecil, sebelum mereka bersekolah, takkan hilang lagi dari mereka sepanjang usianya. Perolehan ini akan tetap dimilikinya, kemanapun mereka pergi kemudian. Dasardasar hidup rohani manusia diletakkan pada masa mudanya, yakni di dalam rumah tangganya sendiri. Alangkah indahnya menerima tugas dari Tuhan, baik sebagai orangtua, maupun selaku pendeta, untuk membina keluarga itu sampai benar-benar bersifat Kristen.

Iman bertumbuh oleh karena mendengarkan Firman Tuhan. Dari sisi mendengar, maka aspek pertumbuhan iman seseorang itu konkrit adanya. Hal itu terjadi pada saat wahyu adikodrati menerobos sistem mental manusia yang mendengarkan dan

\footnotetext{
${ }^{15}$ Louis Berkhof \& Cornelius Van Til, Foundations of Christian Education (Surabaya: Momentum, 2004), 102.

${ }^{16}$ E.G. Homrighausen \& I.H. Enklaar, Pendidikan Agam Kristen (Jakarta: BPK Gunung Mulia, 2007), 137.
}

memperbaharui kualitas hidupnya secara konkrit. Dalam bahasa teologis, aspek perilaku yang terkoreksi, cara hidup yang devian serta gaya hidup bebas nilai kini terkondisikan ke dalam kebenaran suprarasional. ${ }^{17}$

Dasar untuk takut akan Tuhan adalah pengetahuan akan diri-Nya. Hal ini dapat ditelusuri dari kekayaan wahyu Allah di dalam Alkitab. Aspek pengetahuan tentang Yahweh Elohim inilah akan membawa individu tersebut bertumbuh. Batasan ini dimaknai Van Gemeren sebagai sikap kerendahan hati. Beliau mengatakan, kerendahan hati dimulai dengan takut akan Tuhan. Istilah ini diartikulasikan sebagai sikap tunduk kepada Allah.

Lebih jauh Van Gemeren menuliskan, tunduk merupakan sikap pengabdian kepada Allah, kepada tujuan-Nya dan kebebasanNya untuk mengerjakan rencana-Nya dalam mendirikan kerajaan-Nya. Kaitannya dengan iman adalah adanya kebutuhan iluminasi ilahi dan mengekspresikan dirinya dalam keterbukaan untuk melihat dan mendengar dengan hati yang beriman. ${ }^{18}$

Pengetahuan yang telah dimiliki relasinya dengan pemahaman baru, meminjam istilah pedagogik Winkel ${ }^{19}$, terkait erat dengan kerangka kognitif yang telah dimiliki. Konteksnya bila dielaborasikan ke dalam kehidupan jemaat yang mendengarkan Firman Tuhan, maka Roh Kudus akan menyertai mereka yang rendah hati untuk menggugah pemahaman mereka serta memberi mereka struktur-struktur pemahaman baru dalam kehidupan. ${ }^{20}$ Itulah

\footnotetext{
${ }^{17}$ Rubem Cesar Fernandes, "messianism" dalam William Outhwaite, Pemikiran Sosial Modern (Jakarta: Kencana, 2008), 511. Penulis artikel ini mengatakan, rasionalisme modern menentang transendensi.

${ }^{18}$ Willem A Van Gemeren, Penginterpretasian Kitab Para Nabi (Surabaya: Momentum, 2007) 65.

${ }^{19}$ W.S. Winkel, Psikologi Pengajaran (Yogyakarta: Media Abadi, 2004), 405.

${ }^{20}$ Willem A Van Gemeren, Penginterpretasian Kitab Para Nabi (Surabaya: Momentum, 2007), 65.
} 
sikap tunduk dan rendah hati yang dikehendaki Tuhan. Adapun hakikat pertumbuhan iman individu dan dalam kolektivitas persekutuan sangat dipengaruhi oleh sikap tunduk dan kerendahan hati serta peran sentral Roh Kudus bagi pertumbuhan iman yang bersangkutan.

Albert Bandura dengan teorinya kognitif sosial melihat kehidupan siswa sebagai insan pembelajar dalam model deterministik resiprokal pada bingkai pembelajaran mereka. ${ }^{21}$ Di mana ada tiga faktor ultima di dalam pertumbuhan mereka, yaitu: perilaku, person/kognitif dan lingkungan. Ranah kognitif didalamnya mencakup ekspektasi, keyakinan, strategi, pemikiran dan kecerdasan yang bersangkutan. Keterkaitan antara perilaku, person/kognitif dengan lingkungan dalam pokok penelitian ini menunjukkan betapa peran penting penguasaan Firman Tuhan oleh Pembina/Pendeta/Gembala jemaat. Dia dapat memberikan pengaruh yang konstruktif baik untuk diri individu maupun anggota persekutuan tersebut menuju kepada pendewasaan imannya di dalam Kristus Yesus. Tuhan ingin melepaskan seluruh kasih-Nya di dalam hidup kita, agar kita tidak perlu lagi bergerak di dalam hidup lama yang penuh dosa. Selaras dengan itu kehendak Allah agar melalui iman jemaat, Kristus diam di dalam mereka dan mereka berakar serta berdasar di dalam kasih. Itulah sebuah kepenuhan hidup di dalam Kristus. ${ }^{22}$

\section{Kajian Teoritis Pemberitaan Firman Tuhan}

\section{Hakikat Pemberitaan Firman Tuhan}

Dimensi pemberitaan Firman Tuhan bagi Rasul Paulus begitu sentral dalam tugas dan karya pengabdiannya kepada Kristus. Kisah Rasul 17 adalah salah satu contoh kongkrit bagaimana "berita" dan "pem-

\footnotetext{
${ }^{21}$ John W. Santrock, Psikologi Pendidikan (Jakarta: Prenada Media Group, 2007), 285.

${ }^{22}$ Os Hillman, The 9 to 5 Window (Jakarta: Penerbit Imanuel, 2007), 86.
}

beritaan" oleh "si pemberita" mampu menembus ranah kognitif dan bangunan kultural/paradigma yang mendengarkan pada saat itu. Berikut kutipan dari teks tersebut, "Dan juga beberapa ahli pikir dari golongan Epikuros dan Stoa bersoal jawab dengan dia dan ada yang berkata: "Apakah yang hendak dikatakan si peleter ini?" Tetapi yang lain berkata: "Rupa-rupanya ia adalah pemberita ajaran dewa-dewa asing." Sebab ia memberitakan Injil tentang Yesus dan tentang kebangkitan-Nya. Lalu mereka membawa Paulus ke pertemuan di Bukit Areopagus. Di sana mereka berkata kepadanya, "Kami ingin tahu pengajaran baru yang engkau beritakan itu (ayat 17 dan 18). "Paulus pergi berdiri di atas Areopagus dan berkata: "Hai orangorang Atena, aku lihat, bahwa dalam segala hal kamu sangat beribadah kepada dewadewa. Sebab ketika aku berjalan-jalan di kotamu dan melihat-lihat barang-barang pujaanmu, aku menjumpai juga sebuah mezbah dengan tulisan: Kepada Allah yang tidak dikenal. Apa yang kamu sembah tanpa mengenalnya, itulah yang kuberitakan kepada kamu. Allah yang telah menjadikan bumi dan segala isinya, Ia, yang adalah Tuhan atas langit dan bumi, tidak diam dalam kuil-kuil buatan tangan manusia, (ayat 22-24). "dan juga tidak dilayani oleh tangan manusia, seolah-olah Ia kekurangan apa-apa, karena Dialah yang memberikan hidup dan nafas dan segala sesuatu kepada semua orang. Dari satu orang saja Ia telah menjadikan semua bangsa dan umat manusia untuk mendiami seluruh muka bumi dan Ia telah menentukan musim-musim bagi mereka dan batas-batas kediaman mereka, supaya mereka mencari Dia dan mudah-mudahan menjamah dan menemukan Dia, walaupun Ia tidak jauh dari kita masing-masing (ayat 25-27). "Dengan tidak memandang lagi zaman kebodohan, maka sekarang Allah memberitakan kepada manusia, bahwa di mana-mana semua mereka harus bertobat. Karena Ia telah menetapkan suatu hari, pada waktu mana Ia dengan adil akan menghakimi dunia oleh seorang yang telah ditentukan-Nya, sesudah Ia memberikan kepada semua orang suatu bukti 
tentang hal itu dengan membangkitkan Dia dari antara orang mati." (ayat 30-31)".

Contoh lain dapat dilihat dalam nasihat Rasul Paulus kepada orang muda Timotius untuk tidak malu bahkan siap sedia selalu memberitakan Firman Tuhan. Katanya "sementara itu, sampai saya datang nanti, engkau harus bersungguh-sungguh membacakan Alkitab kepada orang-orang, dan mendorong serta mengajar mereka" (1 Timotius 4:13). Paulus mengingatkan waktu akhir jaman yang semakin mendekat ini, sehingga pemberitaan Firman memberikan pengaruh yang kuat bahkan mampu "menyelamatkan" orang yang mendengarkannya, cepat atau lambat. Dorongan dan motivasi untuk bergumul memahami dan menerapkan isi Alkitab adalah melalui pemberitaan Firman Tuhan, selain di dalam persekutuan jemaat.

Konteks pemberitaan Firman Tuhan dalam ibadah merupakan bagian utama dari kebanyakan perayaan di gereja. Kebaktian Minggu yang diselenggarakan setiap pekan diisi dengan pemberitaan Firman Tuhan. Dalam pokok ini, Barna mengatakan berdasarkan hasil risetnya menggambarkan pemberitaan Firman Tuhan memiliki peran yang amat penting. Hal ini menjadi faktor penting dalam proses perkembangan iman jemaat. ${ }^{23}$

Pemberitaan Firman Tuhan dalam suatu komunitas di Gereja Kristen Setia Indonesia (GKSI), jemaat Taman Mini, Jakarta Timr, dapat menjadi contoh bagaimana gereja yang berusaha untuk mengajar jemaatnya mendengarkan kebenaran sejati dari Alkitab. Alkitab sebagai sumber kebenaran tersebut dapat diandalkan untuk memberi hikmat bagi semua golongan usia.

Melalui pemberitaan Firman Tuhan juga dapat digariskan kebutuhan jemaat untuk dikuatkan dan saling menguatkan akan terpenuhi. Hal inilah yang disadari sebagai tantangan gereja agar relevansi kebenaran dapat menyentuh kehidupan konkrit jemaat setempat. Cully mengatakan, gereja selalu

23 George Barna, The Habits of Highly Effective Churches (Malang: Gandum Mas, 2005), 109. terancam bahaya. ${ }^{24}$ Dimensi pemberitaan Firman Tuhan untuk membentengi pengaruh dan ancaman dari luar sangat kontributif dan apologetik.

Rooijakkers menyimpulkan bahwa tugas pengajaran dari para pendidik, baik untuk tugas kerohanian maupun pendidikan umum adalah menumbuhkan dan menyempurnakan pola laku, membina kebiasaan dan kemahiran agar mampu menyesuaikan diri dengan keadaan yang berubah-ubah. ${ }^{25}$ Batasan beliau ini dalam kaitannya dengan pemberitaan Firman Tuhan amat bersentuhan dengan kemampuan untuk mendorong proses pertumbuhan iman jemaat dan menyempurnakan perilakunya, kebiasaannya serta kemampuan mereka mengembangkan dirinya dalam beradaptasi terhadap lingkungan yang terus berubah. Inilah salah satu aspek lain dari pemberitaan Firman Tuhan yakni kuasa untuk menumbuhkan iman jemaat secara aktual dan kontekstual.

Kuasa inilah yang dalam Perjanjian Baru dikenal sebagai karya dari Roh Kudus. Pemberitaan Firman Tuhan tanpa keterlibatan Roh Kudus akan membawa kepada suasana Kebaktian Minggu dan persekutuan jemaat menjadi hambar. Pengetahuan semata tanpa karya Roh Kudus hanya akan membuat pikiran jemaat penuh dengan kalimat-kalimat hampa, tetapi hati jemaat sebenarnya kosong, tanpa kesadaran baru akan kehadiran Allah.

Pemberitaan Firman Tuhan krusial bagi pemenuhan hati jemaat dengan Roh Allah. Barna menyebutkan bahwa hanya apabila kita sepenuhnya memusatkan diri kepada Allah dan sepenuhnya bertekad untuk bergaul dengan Allah dengan cara yang tepat, maka hadirat Allah akan memudahkan perubahan hidup jemaat tersebut. ${ }^{26}$ Hal ini menjadi sebuah perjumpaan riil dengan Allah yang hidup melalui pemberitaan Firman Tuhan yang penuh kuasa.

24 Iris V. Cully, Dinamika Pendidikan Kristen (Jakarta: PT. BPK Gunung Mulia, 2006), 44.

25 Ad. Rooijakkers, Mengajar Dengan Sukses

(Jakarta: PT. Grasindo,1991), xix.

26 George Barna, The Habits of Highly Effective Churches (Malang: Gandum Mas, 2005), 95. 
Perubahan hidup akibat intervensi Allah secara konkrit dalam kehidupan iman jemaat memiliki implikasi lanjutan, yakni sebuah kesaksian iman yang semakin meluas. Sebuah narasi yang disampaikan oleh Injil Yohanes misalnya, ketika Yesus menjumpai perempuan Samaria di sumur Yakub di Sikhar. Kisah ini adalah teladan bagi konteks kesaksian iman yang meluas ke orang-orang lain. Yesus memberitahukan wahyu dari Allah kepada sang perempuan, lalu dia bertobat. Hasilnya bukan hanya perubahan cara hidup perempuan itu, tetapi juga ada banyak orang Samaria di kota itu menjadi percaya kepada Yesus (Yohanis 4:39). Inilah yang dapat dikenal dengan sebutan catatan kegiatan penyelamatan Allah dalam sejarah seseorang. Cully menyebutkan momen ini sebagai peristiwa yang harus diingat dan diterjemahkan agar menjadi relevan kepada orang lain. Pengajaran tentang karya penyelamatan Allah menemukan dinamika riil pada setiap kerygma dari orang-orang yang beriman, di saat merka mengalami dalam situasi-situasi khusus. ${ }^{27}$

Agustinus Gianto mengatakan bahwa Yang Maha Kuasa yang datang dan bersabda kepada manusia adalah kebenaran yang dipersaksikan Yesus lewat seluruh ke-hidupanNya. Kesaksian ini baru dapat didengarkan bila yang bersangkutan berasal dari "kebenaran" itu sendiri. Maksudnya adalah pada saat Roh Kebenaran menerangi yang bersangkutan. ${ }^{28}$ Uraian Gianto tersebut tidak lain merujuk kepada esensi pemberitaan Firman Tuhan bahwa Sabda kebenaran dapat dipahami oleh umat Tuhan bila umat dikaruniakan kekuatan atau kuasa ilahi. Kuasa ini datang dari Allah, memperhatikan nasib manusia dan memulihkan hidupnya.

Kehidupan jemaat mula-mula juga diwarnai dengan pengajaran/pemberitaan Firman Tuhan. Dasar pengajarannya bukan lagi Taurat tetapi Yesus sebagai Penebus dan

27 Iris V. Cully, Dinamika Pendidikan Kristen (Jakarta: BPK Gunung Mulia, 2006), 41. 28 Agustinus Gianto, Langkah-Nya...langkah-ku (Yogyakarta: Kanisius, 2005), 49.
Tuhan. ${ }^{29}$ Dinamika hidup beriman dalam Kristus karena pengajaran dan pemberitaan Firman Tuhan meluas kepada banyak orang lain pada masa itu. Kesaksian hidup dari jemaat mula-mula yang telah diubah kuasa Roh Kudus memampukan mereka untuk mengajar dan berkhotbah kepada banyak orang, sehingga mereka pun percaya kepada Yesus Kristus.

Dampak langsung dari pemberitaan Firman Tuhan menurut Homrighausen dan Enklaar $^{30}$ adalah tumbuhnya kesetiaan dan kerajinan Israel dalam menjalankan kesaksian imannya. Ketaatan umat nampak baik di dalam rumah-rumah, kepada tetangganya, di dalam kebaktian dan kepada siapa saja yang suka mendengarkan berita kesukaan yang mereka siarkan.

Hidup yang penuh telah diterima dari Allah yang absolut. Hidup ini harus dibagikan kepada orang lain yang membutuhkan kasih Allah. Jemaat membagikan hidup yang melimpah kasih Allah ini berdasarkan pada adanya persekutuan pribadi dengan Allah Yahweh. Berkhof dan Van Til mengatakan bahwa melalui persekutuan bersama Dia, kita memiliki hidup yang penuh. Kita memiliki Allah yang absolut yang dapat memberikan kita pengertian dalam usaha kita untuk menjadi saksi-Nya di dunia ini. ${ }^{31}$ Pengaruh dari pemberitaan Firman Tuhan yang benar dan akurat adalah terjalinnya persekutuan dengan Allah Yahweh. Dialah satu-satunya yang dapat memberi kepastian bahwa makna hidup yang kita miliki pada hari ini akan dimengerti sepenuhnya kelak.

Hal itu ditegaskan oleh Rasul Paulus kepada penerus pelayanan kabar baik Kristus yakni Timotius, anak rohaninya. Di dalam 2 Timotius 3:10-14, Paulus mengatakan: "Tetapi engkau telah mengikuti ajaranku,

29 E.G. Homrighausen \& I.H. Enklaar,

Pendidikan Agam Kristen (Jakarta: BPK

Gunung Mulia, 2007), 8.

30 E.G. Homrighausen \& I.H. Enklaar, Pendidikan Agam Kristen (Jakarta: BPK Gunung Mulia, 2007), 8.

31 Louis Berkhof dan Cornelius Van Til, Foundations of Christian Education (Surabaya: Momentum, 2004), 202. 
cara hidupku, pendirianku, imanku, kesabaranku, kasihku dan ketekunanku. Engkau telah ikut menderita penganiayaan dan sengsara seperti yang telah kuderita di Antiokhia dan di Ikonium dan di Listra. Semua penganiayaan itu kuderita dan Tuhan telah melepaskan aku dari padanya. Memang setiap orang yang mau hidup beribadah di dalam Kristus Yesus akan menderita aniaya, sedangkan orang jahat dan penipu akan bertambah jahat, mereka menyesatkan dan disesatkan. tetapi hendaklah engkau tetap berpegang pada kebenaran yang telah engkau terima dan engkau yakini, dengan selalu mengingat orang yang telah mengajarkannya kepadamu." (2 Tim 3:10-14).

Firman Tuhan yang diberitakan berkenaan dengan ajaran, cara hidup, pendirian, iman, kesabaran, kasih dan ketekunan. Nasihat Paulus ini bermanfaat bagi Timotius ini untuk bersikap sama dengan teladan hidup yang telah Paulus berikan. Sebagai pribadi yang telah dipanggil, dipilih dan ditetapkan untuk pemberitaan Firman Tuhan, Paulus dan Timotius mampu menghadapi penganiayaan dan sengsara yang amat berat pada saat itu. Paulus mengingatkan hal itu kepada Timotius agar tidak sekali-kali melupakan sumber pengajaran yang dia terima sebelumnya dari tengah-tengah komunitas jemaat Tuhan. Pemberitaan Firman Tuhan di dalam komunitas beriman merupakan kegiatan untuk mengenalkan anggota komunitas kepada Kristus, Tuhan dan Juru Selamat. Sproul mengatakan, pemberitaan Firman Tuhan akan menuntun seseorang kepada keselamatan oleh iman kepada Kristus Yesus. ${ }^{32}$ Timotius telah mengalami lewat Nenek dan Ibunya, sehingga tugas selanjutnya adalah meneruskan Injil keselamatan itu kepada orang lain.

Melalui pemberitaan Firman Tuhan maka jemaat dapat memahami rencana Allah sejak kekekalan menuju kepada kekekalan. Dalam aras pemberitaan ini, Packer menyebutkan, rencana Allah atas zaman ini adalah supaya Injil ini tersebar di seluruh

\footnotetext{
${ }^{32}$ R.C. Sproul, Depending Your Faith (Malang: Literatur SAAT, 2008), 194
}

dunia, sebagai nats yang mengatakan "suatu kumpulan besar... dari segala bangsa dan suku dan kaum dan bahasa" (Wahyu 7:9) dibawa untuk percaya kepada Kristus. ${ }^{33}$ Pemberitaan Firman Tuhan meneguhkan keyakinan akan eskatologis yang penuh di dalam Kerajaan Allah.

Mengacu kepada Mazmur 119:130, pemberitaan Firman Tuhan pada hakikatnya adalah memberikan pencerahan dan pengalaman iman untuk mengerti kehendak Tuhan secara lebih baik. Jemaat yang mendengarkan Firman Tuhan, menyimpannya di dalam hati serta mau melakukannya setiap hari, adalah orang-orang yang bijaksana dan yang hidupnya berkenan kepada Allah. Cermin yang paling jernih bagi hati dan jiwa terdalam adalah melalui "cermin" yakni Firman Tuhan yang diberitakan. Dasarnya adalah Ibrani 4:12, "For the word of God is living, and active, and sharper than any two-edged sword, and piercing even to the dividing of soul and spirit, of both joints and marrow, and quick to discern the thoughts and intents of the heart."

Budaya yang lahir dari paham postmodernisme merupakan budaya yang kontra terhadap Alkitab. Dalam bahasan Welch, budaya ini disebut dengan menghindari penghakiman moral terhadap perilaku yang dibuat seseorang. ${ }^{34}$ Pembalikan pola pikir dan perilaku hanya dapat dilakukan ketika seseorang mengenal kebenaran Allah terlebih dahulu. Ketika Firman Tuhan diberitakan maka lahirlah kesadaran akan dosa dan penghukuman, serta kebutuhan untuk meminta tolong agar dirinya dilepaskan dari tawanan dosa.

Dari berbagai telaah teori di atas, maka peneliti menyimpulkan bahwa pemberitaan Firman Tuhan sangat penting bahkan merupakan suatu yang ultima bagi pembentukan akhlak dalam usaha menuju keserupaan dengan Kristus. Disamping itu, pembenahan cara hidup agar terus menerus diperbaharui di

\footnotetext{
${ }^{33}$ J.I. Packer, God's Plans For You (Surabaya: Momentum, 2004). 14.

${ }^{34}$ Edward T. Welch, Addiction: A Banquet in The Grave (Surabaya: Momentum, 2007), 22.
} 
dalam Roh Kudus hanya mungkin lewat asupan Firman Tuhan yang didengar lewat setiap pemberitaan Firman Tuhan. Sesungguhnya, melalui pemberitaan Firman Tuhan, seseorang yang telah terpuruk dan jatuh ke dalam lembah dosa akan mendapatkan pemulihan total dari Tuhan. Restorasi ke dalam hidup yang baru, yang terlepas dari dosa terjadi oleh karena Firman Tuhan yang berkuasa dan Roh Kudus yang bekerja di dalam Firman Tuhan tersebut.

Pembatasan mengenai pemberitaan Firman Tuhan dideskripsikan sebagai arena kesaksian di tengah-tengah jemaat Tuhan, di mana aspek pemberitaan kebenaran Allah dinyatakan di tengah-tengah umat. Dampaknya kehidupan jemaat didasarkan kepada Firman Tuhan yang hidup dan diteguhkan oleh kehadiran Roh Kudus sehingga membawa mereka untuk hidup di dalam kekudusan Tuhan dan membawa lebih banyak orang mengenal Kristus. Ketika mereka melekat kepada Firman Tuhan maka kesaksian hidup mereka lahir dari pekerjaan Tuhan dan kuasa Roh Kudus-Nya.

Selanjutnya dapat diinferensialkan indikator dari pemberitaan Firman Tuhan adalah: (a) tugas dan pengabdian, (b) pemberian dorongan, (c) keselamatan bagi pendengar/umat Allah, (d) perkembangan iman jemaat, (e) kebenaran sejati, (f) menguatkan jemaat, (g) melindungi dari pengaruh luar, (h) memberi pertanggungan jawab iman/apologetis, (i) menyempurnakan perilaku atau belajar hidup kudus, (j) memperbaiki kelakuan (k) mendidik hidup dalam kebenaran, (l) kesaksian iman, (m) berhubungan dengan kuasa Allah, (n) isinya mengenai pribadi Yesus Kristus, (o) kerajinan dan kesetiaan, (p) moralitas jemaat.

\section{Hakikat Kualitas Persekutuan}

Hakikat persekutuan baru muncul dalam Perjanjian Baru. Kata yang dipergunakan adalah koinonia. Kata ini terutama banyak ditemukan di dalam surat-surat Paulus. Hakikat dari persekutuan ini dalam PL dipahami sebagai perjanjian antara Allah dengan Israel. Keeratan hubungan mereka ini diungkapkan dalam Mazmur 42 dan Mazmur 63. Browning menyebutkan, persekutuan atau persahabatan orang-orang percaya merupakan persatuan kasih, pertama-tama karena "baptisan, dan kemudian dipelihara melalui persekutuan untuk Perjamuan Tuhan (1 Korintus 11:17-34). ${ }^{35}$ Dasar bagi persekutuan jemaat adalah kasih Kristus kepada jemaat-Nya.

Prakarsa persekutuan datang dari Allah. Demi keselamatan umat-Nya dan bagi pertumbuhan rohani mereka maka Dia mendisiplinkan umat-Nya. Dasar bagi pernyataan ini adalah di Filipi 1:6 yang menyatakan "Ia yang memulai pekerjaan yang baik di antara kamu, akan meneruskannya sampai pada akhirnya pada hari Kristus Yesus". Dengan kata lain, Allah sendirilah yang mengawasi dan memprakarsai pertumbuhan rohani orang percaya. ${ }^{36}$

Sangat menarik untuk melihat urgensitas persekutuan dalam kaitannya dengan kondisi gereja pada saat ini. Orang benar hidup dalam persekutuan dengan Allah (personal style) dan dengan sesama orang benar (communal style). Kedua-duanya terintegrasi dalam satu gaya hidup yang dikenal dengan nama murid Kristus. Owen mengatakan Alkitab ditulis bukan hanya untuk mengungkapkan keadaan orang-orang benar di kemudian hari kelak, tetapi sekaligus juga menyatakan keadaan mereka selama hidup di dunia ini. ${ }^{37}$ Persekutuan jemaat adalah sarana untuk menolong jemaat berpikir dan hidup secara rohani.

Secara implisit Yesus mengajarkan tentang persekutuan. Hal itu dapat dilihat dalam Yohanes 15 mengenai ilustrasi Pokok Anggur Yang Benar, dengan murid-muridNya sebagai ranting-ranting dari Pokok Anggur tersebut. Sebuah alegori dari penulis kitab Injil Yohanes, persekutuan Kristen berakar dalam hubungan Bapa dan Anak

\footnotetext{
${ }^{35}$ W.R.F. Browning, "Persekutuan" dalam Kamus Alkitab (Jakarta: BPK Gunung Mulia, 2007), 352.

${ }^{36}$ Jerry Bridges, The Discipline of Grace (Bandung: Pionir Jaya, 2007), 90.

${ }^{37}$ John Owen, Berpola Pikir Rohani (Surabaya: Momentum, 2001), 30.
} 
(Yohanis 17:2-23). ${ }^{38}$ Persekutuan juga memperoleh penerapan praktisnya di dalam kegiatan Perjamuan Kudus.

Mendalami makna dari persekutuan adalah menerima dan meraih janji-janji Allah kepada orang percaya. Janji yang dinyatakan di dalam diri Kristus. Janji Allah dimeteraikan oleh kematian Yesus Kristus di kayu salib. Di dalamnya terbersit pertumbuhan rohani yakni ke-iman-an orang tersebut kepada Yesus. Owen mengatakan, kematian Kristus secara aktual menghasilkan semua hal baik yang disajikan berdasarkan persetujuan-Nya dengan Bapa, yaitu untuk memberikan manfaat bagi mereka yang secara aktual menerima manfaat tersebut. ${ }^{39}$ Inilah yang dikatakan oleh Paulus mengenai persekutuan, yakni latihan dalam beribadah agar menjadi murid yang terlatih sebagai pemenang." Pada salib itu Kristus membuat segala roh-roh yang memerintah dan berkuasa menjadi tidak berdaya lagi. Mereka dijadikan tontonan umum pada waktu Kristus menggiring mereka sebagai tawanan dalam pawai kemenangan-Nya" (Kolose 2:15).

Persekutuan jemaat adalah keluarga Allah. Dalam 1 Timotius 3:15, ditegaskan bahwa melalui persekutuan di tengah-tengah jemaat, kehidupan ini memberikan perlindungan dan rasa aman serta di mana berdoa dan beribadah dilakukan di tengah persekutuan umat Tuhan. "Jadi jika aku terlambat, sudahlah engkau tahu bagaimana orang harus hidup sebagai keluarga Allah, yakni jemaat dari Allah yang hidup, tiang penopang dan dasar kebenaran. Di dalam persekutuan orang benar, nilai-nilai kehidupan, penopangan (sustainance) dan kebenaran (truth) dapat dialami bagi semua orang yang terlibat di dalamnya.

Persekutuan jemaat berkaitan dengan disiplin. Keselamatan yang telah diterima dengan iman karena pengorbanan Kristus tidak mungkin terpisah dari disiplin rohani. Dalam batasan ini Bridges menyebutkan, anugerah yang menyelamatkan kita, justru

\footnotetext{
${ }^{38}$ W.R.F. Browning, "Persekutuan" dalam Kamus Alkitab (Jakarta: BPK Gunung Mulia, 2007), 353.

${ }^{39}$ John Owen, Kematian Yang Menghidupkan (Surabaya: Momentum, 2001), 49.
}

harus mendisiplin kita juga. ${ }^{40}$ Ketika orang terbiasa dengan disiplin, maka mereka akan melakukan sesuatu dengan sungguhsungguh. ${ }^{41}$ Persekutuan jemaat akan menghasilkan pertumbuhan iman yang bukan sekedar baik tetapi hebat, sehingga terobosan iman menjadi hal yang lumrah.

Kerap kali orang tidak mengalami breaktrough oleh karena mereka sebagai umat Tuhan kurang mengabaikan disiplin rohani yang didapat melalui persekutuan. Model disiplin dalam persekutuan adalah keterlibatan seseorang secara nyata dan terusmenerus di dalam komunitas umat percaya. Menerima dan memahami orientasi persekutuan akan membuat anggota tubuh Kristus dapat mengasihi satu dengan yang lain. $^{42}$

Konteks persekutuan adalah juga konteks moral. Sikap yang signifikan terhadap kebenaran berupa sikap rendah hati dan tulus memungkinkan anggota jemaat berperilaku otentik dan sehat dalam mengembangkan hubungan baik dengan Tuhan dan juga dengan sesama. Inilah sebuah panggilan Kristus agar jemaat-Nya memiliki hati nurani yang kuat. Tidak mudah menyerah dan mampu membedakan apa yang baik dan berkenan kepada Allah. Melalui persekutuan jemaat, maka pembentukan hati nurani yang kuat dapat menjadi landasan kokoh bagi kehidupan pribadi yang lebih baik, kehidupan bermasyarakat yang semakin peduli serta memiliki perilaku etis yang semakin bermoral. ${ }^{43}$

Ranah persekutuan jemaat juga dapat diberi makna sebagai latihan untuk belajar hidup kudus. Kata kudus berlawanan dengan kata dosa. Dalam kaitan inilah, persekutuan jemaat adalah persekutuan di dalam kasih Kristus yang telah menguduskan diri-Nya

\footnotetext{
${ }^{40}$ Jerry Bridges, The Discipline of Grace

(Bandung: Pionir Jaya, 2007), 90.

${ }^{41}$ Jim Collins, Good To Great (Batam: Karisma, 2004), 180.

${ }^{42}$ Soen Siregar, "Motivasi Pelayanan" dalam Kepemimpinan Kristiani (Jakarta: STT Jakarta, 2003), 122.

${ }^{43}$ Michele Borba, Membangun Kecerdasan Moral (Jakarta: Gramedia, 2008), 61.
} 
bagi jemaat. Bridges mengatakan, melalui persatuan kita dengan Kristus, kita telah mati terhadap alam dosa ini. Kita telah dimerdekakan dari dosa (Roma 6:18), dilepaskan dari kuasa kegelapan (Kolose 1:13) dan kembali kepada Allah (Kisah 26:18). ${ }^{44}$ Oleh karena itu, kita ditempatkan di dalam Kerajaan Terang untuk mengerti kebenaran-Nya dan bersaksi tentang-Nya.

Kualitas sebuah persekutuan dapat menjadi penduga apakah persekutuan itu utuh dan dapat diandalkan. Kualitas yang dimaksudkan adalah kualitas hubungan antar pribadi. Maxwell menyebutkan, keutuhan sebuah tim adalah kunci keterandalan yang dapat menciptakan atau menghasilkan keutuhan, yakni mempercayai rekan satu tim Anda, apapun yang terjadi. ${ }^{45}$ Inilah sebuah tim yang dapat menopang anggotaanggotanya untuk dapat bertahan menghadapi masa-masa sukar. Persekutuan di dalam jemaat yang otentik mampu membawa keutuhan bagi semuanya.

Dalam persekutuan jemaat, penemuan makna kebenaran adikodrati adalah sebuah proses. Proses itu terjadi ketika individu yang sedang bergumul atas suatu persoalan hidup yang berat menemukan makna terdalam di balik persoalan tersebut, pada saat kebenaran Firman Tuhan memerdekakan dirinya, bahkan membawa pencerahan atas hidupnya. Hal inilah yang dilihat Teresa Okure ketika menyinggung cara Yesus memimpin perempuan Samaria (Yohanis 4) untuk percaya kepada diri-Nya. Lebih jauh Okure mengatakan, "we have seen that this consists in His leading her through A process of personal discovery. This process is also marked By the technique of arousing curiosity where his suprise of Her rises in a mounting crescendo (give me a drink)". ${ }^{46}$

Melalui persekutuan, jemaat yang haus dan ingin tahu lebih banyak mengenai pergumulan hidupnya dan kebenaran Kristus

\footnotetext{
${ }^{44}$ Jerry Bridges, Mengejar Kekudusan (Bandung: NavPress Indonesia, 2004), 49.

45 John C. Maxwell, The 17 Indisputable Laws of Team work (Batam: Interaksara, 2004), 128.

${ }^{46}$ Teresa Okure, The Johannine Approach to Mission (Tubingen: JCB. Mohr, 1987), 131.
}

baginya dapat bertukar pikiran sehinggga mereka mengalami pertumbuhan iman dan penemuan kebenaran secara utuh. Inilah hakikat dari sebuah persekutuan yang hidup.

Sebuah komunitas baru yang telah diperbaharui terjadi pada saat semua anggota komune menaruh harapannya untuk diberkati oleh Sang Raja Mesianis, yang pemerintahanNya membawa pembaruan dan berkat Allah bagi umatNya. ${ }^{47}$ Dalam batasan ini, persekutuan dapat dikatakan yang telah menghadirkan Mesias di tengah-tengah umatNya sehingga mereka mengalami pelepasan, kemuliaan, kekudusan, dan perhentian sejati. Hal ini tentunya akan membawa semangat bersekutu dan meningkatkan ketaatan jemaat kepada Firman Tuhan, sehingga mereka akan semakin berharap hanya kepada Tuhan (Yesaya 8:17; 10:20-21).

Dinamika persekutuan jemaat pada masa kini dapat dinilai dengan melihat esensi dari persekutuan itu sendiri berdasarkan terang Perjanjian Baru. Persekutuan yang sehat akan menghasilkan kekudusan. John Stott mengutip perkataan James Stalker mengatakan hakikat kekudusan melalui persatuan dengan Kristus dimaknai bagaimana jemaat Tuhan mengerti dan mengalami secara utuh Kristus yang hidup di dalam saya. ${ }^{48}$ Dasar teologisnya adalah keseluruhan pengajaran Paulus berkisar kepada dua kutub yaitu kebenaran melalui kematian Kristus bagi kita dan kekudusan melalui hidup Kristus di dalam kita.

Karakter orang benar mengalami penguatan melalui pendisiplinan. Pendisiplinan menurut Doni Koesoema mempunyai elemen penting yakni gradualitas atau pentahapannya. $^{49}$ Pentahapan dimengerti sebagai kondisi seorang individu mengalami proses untuk dapat mengakuisisi pemahaman moral (tentang benar dan salah) melalui ketaatan, teladan di Alkitab, pengamatan,

\footnotetext{
${ }^{47}$ Willem A. Van Gemeren, Interpreting the Prophetic Word (Surabaya: Momentum, 2007), 283.

${ }^{48}$ John Stott, The Incomparable Christ (Surabaya: Momentum, 2007), 94.

${ }^{49}$ Doni Koesoema A, Pendidikan Karakter (Jakarta: Grasindo,2007),239.
} 
peniruan dan pengulangan peran sebagai saksi Kristus. Inilah arena di mana pertumbuhan iman membumi dalam kehidupan nyata sehari-harinya.

Salah satu aspek lain dari persekutuan adalah terwujudnya asuhan yang positif dan konstruktif, ${ }^{50}$ di mana setiap anggota dapat memberikan kontribusinya bagi pembentukan mentalnya untuk belajar mempercayai orang lain. Dalam konteks persekutuan, orang lain yang dimaksud adalah saudaranya seiman. Arena konstruktif ini kelak akan menghasilkan peneguhan, kesuksesan bersama dan kehidupan yang lebih baru dari sebelumnya. Dengan demikian akan terjadi sebuah peningkatan kualitas hidup secara bersamasama.

Perilaku dan perkembangan perilaku individu dapat mengalami perkembangan yang signifikan dari waktu ke waktu. Aspek kognitif/pengetahuan dan afektif-nya dapat meneguhkan individu untuk mengenal kebenaran secara utuh, disamping karena kematangan emosi yang dia miliki sebelumnya. Kesemuanya ini akan membentuk perkembangan sikap individu ${ }^{51}$ tersebut menjadi saksi Kristus yang efektif.

Dengan demikian, persekutuan yang hidup dapat meningkatkan kemampuan atau kesanggupan individu untuk menjalin hubungan yang lebih luas dengan siapa saja. Pembatasan mengenai persekutuan jemaat diberi makna sebagai kegiatan bersama di dalam aras keyakinan yang sama, yang mempersatukan semua anggota jemaat ke dalam tubuh Kristus, di mana Kristus sebagai Kepala dan jemaat sebagai anggota tubuhNya. Melalui persekutuan yang telah dibentuk oleh karena penebusan Kristus dan pembaharuan hidup oleh kuasa kehadiran Roh Kudus, maka setiap anggota yang loyal akan mengalami peningkatan kualitas hidup secara luar biasa. Bukan hanya itu, mereka akan bertumbuh dalam anugerah, kasih dan

\footnotetext{
${ }^{50}$ John C. Maxwell \& Jim Dornan, Becoming a person of Influence (Jakarta: Harvest Publication House, 2007), 66.

${ }^{51}$ Monty P. Satiadarma \& Fidelis E. Waruwu, Mendidik Kecerdasan (Jakarta: Pustaka Populer Obor, 2003), 70.
}

kebenaran Tuhan. Inilah sebuah cara hidup baru dalam komunitas baru, sebuah komunitas Kerajaan Allah, sebuah gereja yang kudus dan am.

Kualitas persekutuan jemaat harus berpola kepada ajaran Kristus, yang adalah Kepala Gereja. Ajaran ini mengandung janji baik untuk hidup pada hari ini maupun untuk hidup di kehidupan yang baka nanti. Jadi, setiap orang yang mengaku percaya kepada Kristus dan menerima hidup baru di dalamNya dihisabkan ke dalam keluarga Allah, dan diangkat menjadi anak-anak Allah.

Selanjutnya dapat diinferensialkan indikator dari persekutuan jemaat adalah: (a) perjanjian antara Allah dengan umatNya; (b) persatuan kasih dengan Kristus; (c) komunitas murid Kristus prakarsa Allah; (d) hidup dalam disiplin rohani; (e) persekutuan dengan Bapa dan Kristus; (f) menerima dan meraih janji-janji Allah; (g) sebagai keluarga Allah; (h) menuntut kesungguhan; (i) belajar saling mengasihi; (j) belajar hidup kudus; (k) mempercayai saudara seiman dalam keutuhan hidup; (1) belajar tentang kebenaran adikodrati.

\section{Hakikat Pertumbuhan Iman}

Pertumbuhan iman memiliki dua dimensi. Dimensi vertikal sebagai sumber pertumbuhan iman secara pribadi dan dimensi horizontal sebagai sumber kesaksian kepada sesama. Melalui dua dimensi ini, aspek penghayatan memberikan penguatan kepada aspek praksisnya, sehingga pertumbuhan iman dipastikan berlangsung sangat dinamis. Hal ini ditandai oleh sukacita dalam menjalani kehidupan yang penuh perubahan ini. Iman akan bertumbuh berdasarkan kepada kebenaran, yakni kebenaran akan penyataan diri Allah kepada umat-Nya. Dengan kata lain, umat melihat cermin dirinya sendiri, seperti dikatakan oleh Kruse mengutip pendapat Alan Culpeper, “... as a mirror in which we see ourselves 
reacting, learning and discovering the truth", 52

Ketika hati bertautan dengan kebenaran, maka individu yang memberikan respons terhadap kebenaran itu mempercayai adanya sesuatu yang kekuasaan yang berada di luar kemampuan inteleknya, dan merupakan sebuah keinginan kepada sesuatu yang tidak terbatas. ${ }^{53}$ Batasan ini menunjukkan kepada kesadaran individu akan pribadi Allah Pencipta yang melampaui kemanusiaannya. Dalam teks Ibrani 11:1-2 disebutkan bahwa: "Iman adalah dasar dari segala sesuatu yang kita harapkan dan bukti dari segala sesuatu yang tidak kita lihat. Karena beriman, maka orang-orang zaman lampau disenangi oleh Allah". Atas dasar penjelasan Alkitab Firman Allah tersebut, maka dapat dikatakan pula bahwa pertumbuhan iman itu berasal dari Allah. Hal itu terjadi oleh karena mendengarkan Firman Allah yang diberitakan.

Hubungan pertumbuhan iman dalam diri individu dan komunitas orang percaya di sebuah jemaat dengan pemberitaan Firman Tuhan kerap kali dipengaruhi oleh kecendrungan akal untuk bertindak otonom. Berita penyataan Allah adalah Yang Maha Tinggi dan kekal telah mengosongkan diriNya dan mengambil rupa seorang manusia, demi keselamatan manusia itu sendiri melalui pengorbanan diri-Nya. Hal ini bertolak belakang dengan otonomo akal yang cenderung meninggikan diri dan mengklaim diri sebagai pemegang kebenaran. Kedua realitas ini kontras sekali. Otonomi individu yang angkuh berhadapan dengan kerendahan hati Allah, Sang Pencipta. Dilema manusia modern berada pada tataran ini.

Konteks Perjanjian Lama terutama berita tentang perbuatan Allah kepada bangsa-bangsa di luar Israel dapat dibaca dalam kitab Yunus. Di sana diceritakan bagaimana pemberitaan Firman Tuhan yang dilakukan Yunus, walau hanya dalam beberapa kata telah menghasilkan suatu pertobatan yang luar biasa. Bukan hanya raja

\footnotetext{
${ }^{52}$ Colin G. Kruse, John (Cambridge: Wm. B. Eerdmans, 2003), 37.

${ }^{53}$ Emile Durkheim, The Elementary Forms of the Religious Life (Yogyakarta: IRCiSoD, 2006), 50.
}

yang bertobat dan berpuasa, tetapi seluruh penduduk kota juga ikut, bahkan Alkitab mencatat bahwa hewan peliharaan juga ikut berpuasa.

Dengan demikian, seseorang dapat melihat bahwa hakikat pertumbuhan iman memiliki hubungan erat dengan maksud Allah yang diberitakan kepada individu dan bangsa-bangsa. Van Gemeren mengatakan bahwa ketika orang benar membiarkan Allah menjadi Allah dan membuka mata mereka melihat anugerah-Nya dan kasih-Nya, maka mereka mampu melakukan kehendak Allah dengan penuh sukacita. Sebaliknya, ketika mereka mengikat Allah untuk kepentingan mereka sendiri, mereka justru membelenggu diri mereka sendiri. ${ }^{54}$

Pertumbuhan iman seseorang dan pertumbuhan iman komunitas adalah anugerah Allah diberikan kepada umat-Nya. Implikasinya adalah pertumbuhan iman merupakan keselarasan perilaku umat terhadap amanat Allah dan ketaatan umat kepada perintahperintah-Nya. Sebagai instrumen dalam pertumbuhan iman, Allah menyediakan pemberitaan Firman-Nya menjadi alat. Allah juga menghadirkan jemaat yang bertekun di dalam Firman Tuhan dan dalam persekutuan mereka dengan saudara seimannya. Seperti yang disebutkan Pratt, maka tujuan utamanya adalah agar manusia harus berjalan di hadapan Allah dalam pekerjaan baik yang telah Allah persiapkan untuk kita lakukan. ${ }^{55}$ Oleh karena itu, dapatlah ditarik kesimpulan bahwa ranah bagi pertumbuhan iman dalam diri individu yang telah percaya adalah karena anugerah Allah semata. Dialah yang memberikan pertumbuhan dan gereja-Nya sebagai pemberita kebenaran Firman, sekaligus sebagai fasilitator demi terwujudnya persekutuan antar saudara seiman dalam kasih Kristus.

Dari berbagai telaah dekripsi teori di atas, maka peneliti menyimpulkan bahwa pertumbuhan iman adalah tahapan menuju

\footnotetext{
${ }^{54}$ Willem A. Van Gemeren, Interpreting the Prophetic Word (Surabaya: Momentum, 2007), 153.

${ }^{55}$ Richard L. Pratt, Designed For Dignity (Surabaya: Momentum,2002),113.
} 
keserupaan dengan Kristus, di mana iman individu yang bersangkutan disentuh lewat hati yang terbuka dan tulus, serta mau dibentuk sesuai dengan rencana Allah yang kekal. Segi lainnya perlu mendapat pengertian yang lebih komprehensif adalah mengenai posisi gereja sebagai jemaat yang kudus dan am. Di dalam gereja, Allah menyatakan kehadiran-Nya dan kehendakNya bagi umat, agar persekutuan dengan-Nya semakin akrab dan utuh. Inilah aspek moralitas Alkitabiah dari aspek kebersamaan jemaat sebagai Tubuh Kristus, di mana jemaat tahu membedakan apa yang baik, kudus dan berkenan kepada Allah.

Keteguhan iman jemaat adalah suatu keyakinan dan tekad yang muncul dari dalam diri anggota jemaat akan imannya kepada sesuatu yang dia yakini sebagai Tuhan dan Juru Selamat. Keteguhan iman anggota jemaat dapat diukur dengan: a) keyakinan akan yang dia imani; b) teguh pada imannya; c) tidak terpengaruh oleh godaan; d) meyakini janji keselamatan; e) teguh menjalani kehidupan; f) setia dalam penderitaan; g) mendukung persekutuan dan pelayanan; h) hidup dalam persekutuan dengan Allah.

\section{Kesimpulan}

Berdasarkan pemahanan di atas, maka dapat disimpulkan bahwa keterkaitan antara pemberitaan Firman Tuhan dan persekutuan jemaat dengan pertumbuhan iman jemaat adalah bersifat logis, spiritual dan adikodrati. Logis karena hubungan ini dapat dijelaskan dan diterima oleh akal. Spiritual karena pertumbuhan iman tidak bersifat abstrak atau tidak kelihatan. Adikodrati sebab pemberitaan Firman berasal dari Tuhan yang Maha Kuasa dan pertumbuhan iman merupakan relasi manusia dengan Sosok yang Maha Kuasa tersebut. Allah sendiri telah merancangkan pertumbuhan iman melalui pematahan kuasa dosa dan kutuk maut terhadap umat-Nya melalui karya Kristus di kayu salib.
Berdasarkan kepada penjelasan mengenai iman jemaat yang bertumbuh di dalam jemaat, maka jemaat baru dapat dipenuhi oleh kekayaan kasih karunia dan kebenaran Kristus, bila mereka membiasakan diri untuk tekun mendengarkan Firman Tuhan dan melatih dirinya untuk beribadah. Ibadah kepada Tuhan mengandung banyak janjijanji, baik untuk hidup sekarang ini maupun untuk hidup yang akan datang di dalam kekekalan. Aspek utama pemberitaan Firman Tuhan terhadap pertumbuhan iman jemaat adalah Firman Tuhan tidak akan kembali dengan sia-sia bagi setiap orang yang ingin bertumbuh di dalam kebenaran. Kesetiaan mendengarkan Firman Tuhan adalah salah satu bentuk dari otonomi individu yang rela menaklukkan dirinya di bawah teonomi dari Allah.

Aspek utama persekutuan jemaat dengan pertumbuhan iman adalah jemaat merupakan komunitas ilahi sebagai sebuah keluarga di dalam Kerajaan Allah. Komunitas ilahi merupakan sarana jemaat untuk saling mengasihi, saling menopang dan mendukung saudara seiman. Selanjutnya, komunitas ilahi akan menjadi sarana efektif bagi kesaksian jemaat tentang kasih dan kuasa Kristus di sorga maupun di bumi kepada orang-orang lain di luar komunitas gereja.

Akhirnya, dapat juga menyimpulkan bahwa dampak dari pemberitaan Firman Tuhan dan persekutuan jemaat terhadap pertumbuhan iman warga jemaat bersifat positif, rasional dan Alkitabiah. Positif karena pemberitaan Firman Tuhan membawa dampak bagi pertumbuhan iman jemaat agar semakin sesuai kehendak Tuhan. Rasional karena pemberitaan Firman Tuhan dan persekutuan jemaat harus dikelola secara modern sehingga dapat dipahami oleh semua warga jemaat. Alkitabiah karena kebenaran Firman Tuhan yang mengubah hidup manusia itu memiliki unsur kebenaran yang kekal, sebagaimana yang tertulis di dalam Alkitab. 


\section{Daftar Pustaka:}

Rooijakkers, Ad., Mengajar Dengan Sukses. Jakarta: PT. Grasindo,1991.

Gianto, Agustinus, Langkah-Nya...langkah$k u$, Yogyakarta: Kanisius, 2005.

Kruse, Colin G., John. Cambridge: Wm. B. Eerdmans, 2003.

A, Doni Koesoema, Pendidikan Karakter. Jakarta: Grasindo, 2007.

Welch, Edward T., Addiction: A Banquet in The Grave. Surabaya: Momentum, 2007.

Homrighausen, E.G. \& I.H. Enklaar, Pendidikan Agam Kristen. Jakarta: BPK Gunung Mulia, 2007.

Durkheim, Emile, The Elementary Forms of the Religious Life. Yogyakarta: IRCiSoD, 2006.

Barna, George, The Habits of Highly Effective Churches. Malang: Gandum Mas, 2005.

Cully, Iris V., Dinamika Pendidikan Kristen. Jakarta: PT. BPK Gunung Mulia, 2006.

Packer, J.I., God's Plans For You. Surabaya: Momentum, 2004.

Bridges, Jerry, Mengejar Kekudusan. Bandung: NavPress Indonesia, 2004.

Bridges, Jerry, The Discipline of Grace. Bandung: Pionir Jaya, 2007.

Collins, Jim, Good To Great. Batam: Karisma, 2004.

Maxwell, John C. \& Jim Dornan, Becoming a person of Influence. Jakarta: Harvest Publication House, 2007.

Maxwell, John C., The 17 Indisputable Laws of Team work. Batam: Interaksara, 2004.

Owen, John, Berpola Pikir Rohani. Surabaya: Momentum, 2001.

Owen, John, Kematian Yang Menghidupkan. Surabaya: Momentum, 2001.

Stott, John, The Incomparable Christ. Surabaya: Momentum, 2007.

Santrock, John W., Psikologi Pendidikan. Jakarta: Prenada Media Group, 2007.

Berkhof, Louis dan Cornelius Van Til, Foundations of Christian Education. Surabaya: Momentum, 2004
Borba, Michele, Membangun Kecerdasan Moral. Jakarta: Gramedia, 2008.

Satiadarma, Monty P. \& Fidelis E. Waruwu, Mendidik Kecerdasan. Jakarta: Pustaka Populer Obor, 2003.

Munroe, Myles, The Spirit of Leadership. Jakarta: Penerbit Imanuel, 2008.

Hillman, Os, The 9 to 5 Window. Jakarta: Penerbit Imanuel, 2007.

Sproul, R.C., Depending Your Faith. Malang: Literatur SAAT, 2008.

Richard L. Pratt, Designed For Dignity. Surabaya: Momentum, 2002.

Pratt, Richard L., He Gave Us Stories. Surabaya: Momentum, 2005.

Slavin, Robert E., Cooperative Learning. Bandung: Nusa Media, 2008.

Ferguson, Sinclair B., Kehidupan Kristen Sebuah Pengantar Doktrinal. Surabaya: Momentum, 2007.

Siregar, Soen, "Motivasi Pelayanan" dalam Kepemimpinan Kristiani. Jakarta: STT Jakarta, 2003.

Okure, Teresa, The Johannine Approach to Mission. Tubingen: JCB. Mohr, 1987.

Fletcher, Verne H., Lihatlah Sang Manusia. Jakarta: BPK Gunung Mulia, 2007.

Heath, W. Stanley, Tafsiran 2 Korintus Kedewasaan Iman. Bandung: Kalam Hidup, 2008.

Winkel, W.S., Psikologi Pengajaran. Yogyakarta: Media Abadi, 2004.

Browning, W.R.F., Kamus Alkitab. Jakarta: BPK Gunung Mulia, 2007.

Gemeren, Willem A Van, Penginterpretasian Kitab Para Nabi. Surabaya: Momentum, 2007.

Outhwaite, William, Pemikiran Sosial Modern. Jakarta: Kencana, 200.

Bagir, Zainal Abidin, Jarot Wahyudi dan Afnan Anshori, Integrasi Ilmu Dan Agama. Bandung: Penerbit Mizan, 2005. 